\title{
The health-related quality of life of Syrian refugee women in their reproductive age
}

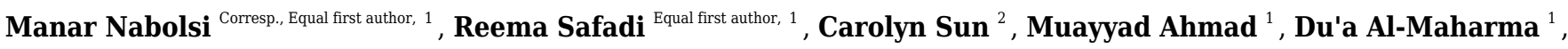 \\ Suhaila Halasa ${ }^{1}$, Mohammad Saleh ${ }^{1}$, Jennifer Dohrn ${ }^{3}$ \\ ${ }^{1}$ School of Nursing, The University of Jordan, Amman, Jordan \\ 2 Hunter Bellevue School of Nursing, Hunter College, New York, United States of America \\ 3 School of Nursing, Columbia University, New York, United States \\ Corresponding Author: Manar Nabolsi \\ Email address: manarn@ju.edu.jo
}

Background. Health-Related Quality of Life (HRQoL) for refugee women in reproductive age is highly affected by physical, political, psychosocial and environmental conditions in countries of asylum. HRQoL is enormously affected by the satisfaction of this vulnerable group with the physical, psychological, emotional and social care services provided in this critical time. Therefore, this study aimed toassess the HRQoL among Syrian refugee women of reproductive age living outside camps in Jordan. Methods. A cross-sectional correlational study was conducted with a convenience sample of 523 Syrian refugee women in the host communities in Jordan. Health-related quality of life (HRQOL) was measured using the short-form 36 (SF-36) questionnaire. Results. Significant negative correlations were found between SF-36 individual subscales score and the length of marriage, the number of children, parity and family income. The strongest correlations were between pain scale and length of marriage $(r=-.21)$, and between Energy/Fatigue and 'number of children' $(r=-.21)$. Conversely, antenatal care was positively correlated with physical, role emotional, pain, and general health. Physical functioning and general health were predicted significantly with less years of marriage, younger age at marriage, less violence and by higher family income. Conclusion. This study suggests low HRQoL scores for women of reproductive age across all domains. Several factors such as years of marriage, age at marriage, the number of children, violence, antenatal care and family income affected the women's general health. The provision of appropriate and accessible reproductive and maternal healthcare services in antenatal visits is critical for ensuring the immediate and long-term health and wellbeing of refugee women and their families. 


\section{Abstract}

2 Background. Health-Related Quality of Life (HRQoL) for refugee women in reproductive age is

3 highly affected by physical, political, psychosocial, and environmental conditions in countries of

4 asylum. HRQoL is enormously affected by the satisfaction of this vulnerable group with the

5 physical, psychological, emotional, and social care services provided in this critical time.

6 Therefore, this study aimed to assess the HRQoL among Syrian refugee women of reproductive

7 age living outside camps in Jordan.

8 Methods. A cross-sectional correlational study was conducted with a convenience sample of

9523 Syrian refugee women in the host communities in Jordan. Health-related quality of life

10 (HRQOL) was measured using the short-form 36 (SF-36) questionnaire.

11 Results. Significant negative correlations were found between SF-36 individual subscales score

12 and the length of marriage, the number of children, parity, and family income. The strongest

13 correlations were between pain scale and length of marriage $(\mathrm{r}=-.21)$, and between

14 Energy/Fatigue and 'number of children' $(\mathrm{r}=-.21)$. Conversely, antenatal care was positively

15 correlated with physical, role emotional, pain, and general health. Physical functioning and

16 general health were predicted significantly with less years of marriage, younger age at marriage,

17 less violence, and higher family income.

18 Conclusion. This study suggests low HRQoL scores for women of reproductive age across all

19 domains. Several factors such as years of marriage, age at marriage, the number of children,

20 violence, antenatal care, and family income affected the women's general health. The provision

21 of appropriate and accessible reproductive and maternal healthcare services in antenatal visits is

22 critical for ensuring the immediate and long-term health and wellbeing of refugee women and

23 their families.

24 Keywords. Health-Related Quality of Life, Syrian refugee, women, Jordan 


\section{Introduction}

26 The conflict in Syria started in 2011 and was declared by the United Nations as one of the

27 world's worst humanitarian crises in the twenty-first century and a public health disaster (Baker, 28 2014). Because of this crisis, an estimated 6.3 million Syrian refugees were forcibly removed

29 from their homes to other countries. About 5.6 million of these refugees fled to neighboring 30 countries, including Lebanon, Turkey, and Jordan (United Nations High Commissioner for 31 Refugees (UNHCR), 2019).

Jordan hosts the second-highest number of refugees (87per 1,000 inhabitants) and is the sixth-highest refugee-hosting country in the world. At the time of this study (2018), 83\% of

34 Syrian refugees in Jordan live in urban areas, and only a smaller percentage of refugees were 35 living in refugee camps concentrated mainly in the north of Jordan (UNHCR, 2018b). The largest proportion of Syrian refugees are living in four major cities, Amman: (34.42\%), Irbid (27.14\%), Mafrak (16.43\%) and Zarka, (13.85\%)(Higher Population Council, 2016). With limited health care resources as a lower-middle income country, promoting and improving refugees' health is taxing to the existing health care system of Jordan. In fact, while Jordan had previously been categorized as an upper-middle income country, in 2017 Jordan was reclassified as a lowermiddle income country, in part because of a growing population including refugees (World Bank, 2017).

The UNHCR figures of (2019) reported that women accounted for $49.9 \%$ of total Syrian

44 refugee men and women residing out of camps in Jordan. Of this population $(49.9 \%, 23.9 \%$ were women between the ages of 18-59 years old. In a world where people are forcibly displaced because of conflict or persecution, women and children are most vulnerable. Refugee women of

47 reproductive age bear a disproportionate share of suffering and hardship due to displacement, 48 war, and conflict situations requiring additional attention to maintain their physical, social and 
49 psychological wellbeing. Health issues such as mental health, reproductive health,

50 communicable and non-communicable diseases are a priority for health care services for this

51 population (Doocy et al., 2015; Hollander et al., 2016; Khawaja et al., 2017; Nelson-Peterman et 52 al., 2015).

Several health issues arise when women escape conflicts and seek refuge in another

54 55

country. Refugee women of reproductive age often encounter challenges in receiving family planning and perinatal care (Mortazavi et al., 2014; Reese Masterson et al., 2014; Sadat et al., 2013). Lack of healthcare at this age may expose women to pregnancy and obstetric complications after birth. Several studies among Afghans, Somalis, Iraqis and Syrian refugees suggest that women face physical and mental health challenges (Alemi et al., 2016; Bogic et al., 2015; Gerritsen et al., 2006; Ghumman et al., 2016; Hassan et al., 2016; Lillee et al., 2015; Maximova \& Krahn, 2010; Taylor et al., 2014). A study by Hassan et al. (2016)_suggested that Syrian women experienced a wide range of mental health problems because of the war and immigration. In another study, Syrian refugee women had an increased risk of suffering from post-traumatic stress disorder (PTSD) when exposed to more than one trauma (Alpak et al., 2015). Alemi et al. (2016) demonstrated that migrants suffered depression, anxiety, and symptoms of psychological distress .In addition to mental and psychological health, in a study of Syrian refugees in Lebanon, Reese Masterson et al. (2014)_found that Syrian women's physical health was affected by several reproductive health problems such as menstrual irregularities, pelvic pain and infections.

Health-Related Quality of Life (HRQoL) is a broad concept covering physical, mental, emotional and social constructs that affect the HRQoL. It is based on a person's level of satisfaction with their physical condition, emotional state, and family and social life, and takes 
72 into account functional aspects in a person's life (Group, 1993; Wilson \& Cleary, 1995). HRQoL

73 is a major issue to be considered in a vulnerable group such as refugee women. Having extra

74 stressors such as pregnancy and childbirth as an immigrant in a different physical, psychosocial

75 and environmental condition puts them at higher risk for physical and mental problems.

76 Additionally, situations like immigration, aggravated by pregnancy and other reproductive needs,

77 low level of education, separation from spouses and children, lack of health insurance and

78 unemployment create serious challenges to maintain adequate healthcare services that promote

79 health and HRQoL in extraordinary conditions. Accordingly, the purpose of this study was to

80 assess health related quality of life of Syrian refugee women in the reproductive age within six

81 months of giving birth to an infant as they live outside the refugee camps in Jordan. This will

82 assist health care providers in planning interventions that enhance health services and guide

83 policy makers in implementing services to promote the health of this vulnerable group.

\section{Materials \& Methods}

85 Design

86 A cross-sectional correlational survey was used in this study.

\section{Sample and Setting}

88 The population of this study comprises Syrian refugee women of reproductive age (14-49 years

89 old) who had given birth within the last six months. A proportional quota sampling technique

90 was used to select women who were living outside the refugee camps in Amman (the capital of

91 Jordan), Irbid, Mafrak and Zarka). Selection was based on the percentage of Syrian refugee

92 women in each city, the four major hosting cities of Syrian refugees (Higher Population Council, 93 2016) 
94 A priori sample size calculation was conducted revealing a sample of at least 393 mothers based

95 on a 0.05 two-tailed level of significance, an effect size $=0.20$ (small), and a power $=0.80$ using

96 mean difference test (Cohen, 1992).

\section{Instruments}

98 The questionnaire consisted of two parts. The first part included questions pertaining to Syrian

99 refugee women sociodemographic characteristics such as age, marital status, educational level,

100 religion, number of children, income level, health insurance, and employment status. The second

101 part included a short survey of the Arabic version of SF-36 of the eight HRQoL dimensions. The

102 SF-36 measures quality of life in eight health domains: physical functioning (10 items), role

103 limitations due to physical health problems (4 items), role limitations due to personal or

104 emotional problems (3 items), energy/fatigue (4 items), emotional well-being (5 items), social

105 functioning ( 2 items), bodily pain ( 2 items), and general health perceptions (5items)(Ware \&

106 Sherbourne, 1992).

107 SF-36 is a valid and reliable tool across diverse populations (McHorney et al., 1994). SF-

10836 Health Survey has been used among the general populations in health and illness conditions

109 and among refugees such as Karenni, Afghani, Iranian and Somali refugees (Cardozo et al.,

110 2004; Gerritsen et al., 2006).

111 The Arabic version form was used to measure the health status of the Arab population in

112 Saudi Arabia, Tunisia, and Lebanon. The tool measurement showed high internal consistency ( $\alpha$

$1130.70-0.90$ ) across the eight subscales (Sheikh et al., 2015). These results suggest that the SF-36

114 Arabic version of the questionnaire is a valid and reliable scale to measure the quality of life of

115 the Arab population. 


\section{Data collection}

118 This report is part of a larger study that examined aspects of reproductive health practices of

119 Syrian refugee women in Jordan. Twenty-seven research assistants (RAs) were recruited and

120 trained by the research team on data collection that took place over a period of six months

121 (January -July 2018). We recruited female RAs to ensure that women felt comfortable as they

122 participated in this study. After training, the instrument and methods were tested on a sample of

12330 Syrian refugee women and was found as clear and relevant. Data were collected in women's

124 homes using face-to-face interviewing techniques. Research assistants assisted illiterate

125 participants by reading each question and completing the form together.

\section{Ethical considerations}

127 Ethical approval was obtained from the University of Jordan and the Department of Statistics

128 (DOS). The DOS's approval was necessary to facilitate RAs access to the host community and

129 collect data from participants. Participants were informed of the purpose and procedures of the

130 study. They were assured of their rights to confidentiality and their right to voluntary

131 participation and to decline participation without reprimands. They were informed that

132 participation has no or minimal risk. Upon approval of participation, each woman was invited to

133 sign a consent form in Arabic. An additional consent was sought from guardians of women under

13418 years old. A copy of this form that included a contact number for the research team was given 135 to participants in case they had additional questions.

\section{Data analyses}

137 The statistical analysis was conducted using the Statistical Package for the Social Sciences

138 (SPSS) version 23.0 for Windows (SPSS Inc. Chicago, IL, USA). The SF-36 survey scores were

139 coded and scored using the guidelines provided by the RAND Corporation (i.e. transformed to 
140 positive score between 0 and 100 where the higher the score, the better the health). For example,

141 for pain, a higher score indicates greater freedom from pain. Pearson correlation coefficient was

142 used to examine the relationship between the total and subscale scores of the SF-36, and

143 demographic variables. Multivariate linear regression analysis was used to identify predictors of

144 Sf-36 subscales

145 Results

146

147 Characteristics of participants

148 A total of 523 Syrian refugee postpartum women participated in the study with a response rate of $14998 \%$. Age ranged from 16 to 44 years $(\mathrm{M} \pm \mathrm{SD}=26.11 \pm 6.11$. Mothers' age at marriage ranged

150 from 12 to 37 years $(\mathrm{M} \pm \mathrm{SD}=18.50 \pm 3.71)$ with a duration of marriage ranging from 1 to 25

151 years $(\mathrm{M} \pm \mathrm{SD}=7.6 \pm 5.3)$. The number of children in the participants' families ranged from 1 to

15211 years $(\mathrm{M} \pm \mathrm{SD}=3.21 \pm 1.84)$. Family's monthly income in Jordanian dinar $(\mathrm{JD} ; 1 \mathrm{JD}=1.41$

153 U.S. dollars) ranged from 30 to $940 \mathrm{JD}(\mathrm{M} \pm \mathrm{SD}=222.6 \pm 105.45)$. The majority of the

154 participants did not experience violence (93.5). Women who have experience abortion one or

155 more times were $37.3 \%$ of the studied participants (Table 1 ).

156

157

158

159

160

161

162

163

164

Table 2 shows the mean, standard deviation, and the Cronbach's alpha for the eight

health dimension scales. Each of the subscales was scored between 0 and 100 . The highest mean was for the physical functioning (66.18) while the lowest mean was for role limitations due to emotional problems (42.83). The reliability coefficients as demonstrated by Cronbach's alpha for the eight health subscales ranged between .61 and .90 .

Table 3 shows the bivariate correlations between the eight health scales with the examined sociodemographic variables. Most importantly, the eight scales showed a significant negative association with (1) years of marriage, (2) number of children, and (3) previous births. 
165 That is, the greater the number of years of marriage, number of children, and number of previous

166 births have negatively affected women's overall quality of life. Additionally, there were two

167 demographic variables: (1) family income and (2) antenatal care that showed positive association

168 with HRQoL scales. Family income was positively correlated with physical functioning $\left(.12^{* *}\right)$

169 and general health $\left(.11^{*}\right)$.Antenatal care was positively correlated with physical $\left(.09^{*}\right)$, role

170 emotional $\left(11^{*}\right)$, freedom of pain $\left(.12^{* *}\right)$,and general health $\left(.10^{*}\right)$,indicating that women who

171 received antenatal care had better quality in the physical, role emotional, freedom of pain, and

172 general health domains. That is, the higher the family income, and the increased number of

173 antenatal visits, the better is the quality of life of women in the reproductive age. There was a

174 negative correlation between violence and emotional wellbeing $(\mathrm{r}=-.10)$. The strongest

175 correlation between HRQoL scales and sociodemographic variables were between 'pain scale'

176 and 'years of marriage' $(r=-.21)$, and between 'Energy/Fatigue' and 'number of children' $(r=$ -

$177.21)$

178 Refugee women's characteristics as predictors for the health conditions are presented in Table 4.

179 Before running the analyses, all the statistical assumptions for multiple linear regression were

180 examined. None were violated. All the eight multiple regression models were significant in this

181 study.

182 The selection of the nine predictors was based on its importance to the refugee women

183 and the statistical correlation with the health scales. The highest explained variance was the same

$184\left(\mathrm{R}^{2}=.07\right)$ for physical functioning, pain, general health scales. Physical functioning was

185 predicted significantly as better health with less years of marriage, younger age at marriage, and

186 with higher family income. The variables (number of children, previous abortion, previous birth,

187 and baby loss) showed poor prediction across all the health conditions. General health was 
188 predicted significantly with better family income and less violence. Freedom of pain was

189 predicted significantly with less years of marriage and antenatal care.

190

191 Discussion

192 This study explored the HRQoL of Syrian refugee women within six months of giving birth and 193 who were living outside of the refugee camps in Jordan. The scores of HRQoL measurement 194 scales and the subscales were compared with women in this study and women living in nearby 195 Arab countries reported in other studies (Daher et al., 2011; Matalqah et al., 2018; Sabbah et al., 196 2003), taking into considerations that these studies may have had different methodologies and 197 have been conducted in different socio-political circumstances. The results of the current study 198 showed that Syrian refugee women living outside of refugee camps in Jordan scored lower on all 199 domains compared to other women living in northern Jordan and Iraqi refugee women.

200 Additionally, Syrian refugee women scored lowest in general health scores compared to 201 Jordanian and Iraqi refugees. This can be explained in light of the psychosocial and physical 202 burden after having a new baby and not being well settled in Jordan, unlike Jordanian, Lebanese 203 and Iraqi women.

204

The highest mean score of the SF-36 scale in the study was the physical functioning. This 205 finding is similar to another study of the Arab populations including Jordanian and Lebanese 206 people. In their study, Sabbah et al., (2003) and Doocy et al., (2015) showed that physical health 207 scores were the highest, whereas, the emotional health scores were the lowest. In another study 208 about the Iraqi refugees, women scored the highest in social functioning. It is probably that Iraqi 209 women were better settled with time elapsing since migration to Jordan and have developed 
210 more social network that enabled them to cope with their needs compared to this study

211 population (Daher et al., 2011).

212 In the current study, there was a decline in physical health with increasing years of

213 marriage, number of children, and older age at marriage; and at the same time, factors that

214 significantly predicted physical functioning were also less years of marriage, younger age at

215 marriage, higher family income, and less violence, all of which are aligned with

216 Mirghafourvand, et al., (2016) study. Such findings may reflect women's energy depleting with

217 increasing requirements to fulfil their assumed role as a caretaker of the family members, a

218 mother, and a wife with an increased number of children and responsibilities. An increasing age

219 and family demands in unusual living conditions, such as in resettlement, may drain a woman's

220 energy and functioning levels.

221

The lowest SF36 score in this study was in role emotional. This result could point to the

222 influence of their emotional condition and their inability to perform their roles as mothers and

223 wives. Being a refugee in a different social and environmental context, compounded by having a

224 new child, without social support, financial strains, and war-related stressful situations are

225

226

227

228

229

230

231

232

aggravating factors that may likely contribute to women's emotional distress. This finding is

consistent with the findings of a study in Northern Jordan (Matalqah et al., 2018). Both

populations (Jordanian and Syrian) are facing similar socioeconomic challenges in poverty and are surrounded by war and political turbulence in neighbouring countries. Alternatively, Iraqi refugee had their lowest score in energy and fatigue scales (Daher et al., 2011), which could be related to their prolonged refuge situation compared to Syrian refugees.

In this study, women who received antenatal care had better health (physical, role emotional, pain, general health). A significant positive correlation was found between income 
233 and antenatal visits with improved HRQoL subscale scores. Jordan is dedicated to providing

234 reproductive health care services to refugees throughout the widespread mother and child care

235 centres and mobile services (Saadallah \& Baker, 2016). However, a study of Syrian refugees in

236 camps reported that 23 percent of refugee women were unaware of these services, about 28

237 percent experienced unplanned pregnancies, and 17 percent did not access antenatal care during

238 their pregnancy (Kohler, 2014).

The strongest correlation was between pain scale and length of marriage. In a study of

240 Jordanian women Matalqah et al., (2018) found that Jordanian women suffered more pain and

241 limitations due to pain compared with this study group, the Syrian refugee women. The other

242 strong correlation was between energy/fatigue and number of children. Women in this study

243 may be overwhelmed with their family's needs, and in the case of refugee women with a large

244 family and large number of children, lack of resources and support, and having a new child. It is

245 no surprise that these responsibilities drain their energy and cause fatigue (Iwata et al., 2018;

246 Schmied et al., 2017).This study suggested that participants' energy and fatigue, and health in

247 general were negatively affected by the increased number of children in the family; this may, in

248 part, lead to increased financial burden. However, with increasing age and length of marriage,

249 women usually develop better adaptation to the increased demands of the family. Age-related

250 changes in coping and adaptation show a curvilinear pattern over the life course, with a peak in

251 midlife and declines in older age (Robinson \& Lachman, 2017).

252 The findings suggest a relationship between low socioeconomic status and poor health.

253 Studies have shown that physical and mental health problems are highly prevalent in vulnerable

254 populations, such as refugees and asylum seekers (Dorling et al., 2007). It was also found that

255 having health insurance has enhanced physical and emotional health. About two-thirds of the 
256 women (68.5\%) in the current study did not have health insurance. As in 2018 and as a result of

257 the national financial burden and the international funding cuts, the Jordanian Government and

258 International organizations have reduced budget plans in providing health care services to

259 refugees. Therefore, refugees have to pay about $80 \%$ of health care services, besides facing the

260 challenges to access basic health care services (Doocy et al., 2015; Kohler, 2014). As a result,

261 there will be an increasingly challenging situation to meet the needs of over 650,000 refugees in

262 the country (UNHCR, 2018a).

263 Vulnerable women such as refugees in their postpartum period may undergo physical,

264 emotional and social changes that may expose them to several health risks (Sadat et al., 2013;

265 Tucker et al., 2010). In this critical period, women may need health care services that improve

266 their HRQoL and wellbeing and prevent comorbidity and complications. The literature has

267 shown that forced displacement of Syrians affected their HRQoL, including their physical

268 (Doocy et al., 2015), psychological (Weinstein et al. 2016), and social wellbeing (Sevinç et al.,

269 2016). This study confirms those findings and highlights specifically the needs of women of

270 reproductive age living outside refugee camps.

\section{Strengths and Limitations}

272 This is the first study to address the HRQoL of Syrian refugees' women during a critical

273 time, shortly after birth at a sensitive period when they needed more support, better health care

274 services, while they were struggling with the refugee status.

275

A survey, self-report design is used in this study. In this design bias may affect the

276 results as participants may be too embarrassed to reveal private details. Accordingly, we

277 recommend further qualitative and longitudinal and study that can enhance our knowledge in

278 examining the HRQoL of vulnerable women. Furthermore, the use of non-random sampling 
279 limited the generalizability of the findings. Further studies to include Palestinian refugee women

280 is recommended.

281 Conclusions

282

283

In this study, we found that the general health and HRQoL of Syrian refugee women

284

were low compared to the findings of other studies of Arab women in the literature.

285 There is a relationship between low socioeconomic status and poor HRQoL. Several factors such 286 as years of marriage, age at marriage, the number of children, violence, antenatal care and family 287 income affected the women's general health. The provision of optimal reproductive and maternal 288 healthcare is critical for ensuring the health and wellbeing of refugee women and their families. For refugee women, access to maternity care influences their immediate and long-term health; it also impacts upon integration, attitudes to health and health-seeking behaviour, and may have health ramifications upon the next generations. Providing equitable access to quality reproductive health services for Syrian refugees and Jordanians poses enormous challenges for a small country like Jordan. in their reproductive age as they face several health challenges related to physical, mental and socioeconomic status. Nurses can play a major role in promoting the health of refugee women. Addressing barriers to seeking health care services and attending to health care needs and providing health education, affordable and accessible health care services can improve Syrian refugee women health and HRQoL. Further studies to include Palestinian refugee women is recommended

\section{Acknowledgements}

303 
304 The authors would like to extend their sincere appreciation for Columbia University President's 305 Global Innovation Fund, for funding this study.

306

307

308

309

310

311

312

313

314

315

316

317

318

319

320

321

322

323

324

325

326

327

328

329

330

331

\section{References}

Alemi Q, Stempel C, Baek K, Lares L, Villa P, Danis D, and Montgomery S. 2016. Impact of Postmigration Living Difficulties on the Mental Health of Afghan Migrants Residing in Istanbul. International Journal of Population Research. 2016:8. 10.1155/2016/7690697

Alpak G, Unal A, Bulbul F, Sagaltici E, Bez Y, Altindag A, Dalkilic A, and Savas HA. 2015. Post-traumatic stress disorder among Syrian refugees in Turkey: a cross-sectional study. Int J Psychiatry Clin Pract 19:45-50. 10.3109/13651501.2014.961930

Baker D. 2014. Regional Situation Report for Syria Crisis. Geneva: United Nations Population Fund. Available at https://syria.unfpa.org/sites/default/files/pubpdf/UNFPA\%20Regional $\% 20$ SitRep $\% 201 \% 20$ \%2030\%20November\%202014\%20\%20\%23\%2027 0.pdf ( accessed 8 March 2020)

Bogic M, Njoku A, and Priebe S. 2015. Long-term mental health of war-refugees: a systematic literature review. BMC Int Health Hum Rights 15:29. 10.1186/s12914-015-0064-9

Cardozo BL, Talley L, Burton A, and Crawford C. 2004. Karenni refugees living in ThaiBurmese border camps: traumatic experiences, mental health outcomes, and social 
332

333

334

335

336

337

338

339

340

341

342

343

344

345

346

347

348

349

350

351

352

functioning. Social Science \& Medicine 58:2637-2644.

https://doi.org/10.1016/j.socscimed.2003.09.024

Cohen J. 1992. A power primer. Psychol Bull 112:155-159.

Daher AM, Ibrahim HS, Daher TM, and Anbori AK. 2011. Health related quality of life among Iraqi immigrants settled in Malaysia. BMC Public Health 11:407-407. 10.1186/14712458-11-407

Doocy S, Lyles E, Roberton T, Akhu-Zaheya L, Oweis A, and Burnham G. 2015. Prevalence and care-seeking for chronic diseases among Syrian refugees in Jordan. BMC Public Health 15:1097. 10.1186/s12889-015-2429-3

Dorling D, Mitchell R, and Pearce J. 2007. The global impact of income inequality on health by age: an observational study. 335:873. https://doi.org/10.1136/bmj.39349.507315.DE

Gerritsen AA, Bramsen I, Deville W, van Willigen LH, Hovens JE, and van der Ploeg HM. 2006. Physical and mental health of Afghan, Iranian and Somali asylum seekers and refugees living in the Netherlands. Soc Psychiatry Psychiatr Epidemiol 41:18-26. $10.1007 / \mathrm{s} 00127-005-0003-5$

Ghumman U, McCord CE, and Chang JE. 2016. Posttraumatic stress disorder in Syrian refugees: A review. Canadian Psychology/Psychologie canadienne 57:246-253. 10.1037/cap0000069

Group W. 1993. Study protocol for the World Health Organization project to develop a Quality of Life assessment instrument (WHOQOL). Quality of Life Research 2:153-159. 10.1007/BF00435734 
353 Hassan G, Ventevogel P, Jefee-Bahloul H, Barkil-Oteo A, and Kirmayer LJ. 2016. Mental health

354

355

356

357

358

359

360

361

362

363

364

365

366

367

368

369

370

371

372

373

374

and psychosocial wellbeing of Syrians affected by armed conflict. Epidemiol Psychiatr

Sci 25:129-141. 10.1017/s2045796016000044

Higher Population Council. 2016. Reproductive health services for Syrians living outside camps in Jordan Available at https://www.hpc.org.jo/sites/default/files/Reproductive\%20Health\%20Services\%20for\%2 0Syrians\%20Living\%20Outside\%20Camps\%20in\%20Jordan.pdf(accessed 15 January 2019).

Hollander A-C, Dal H, Lewis G, Magnusson C, Kirkbride JB, and Dalman C. 2016. Refugee migration and risk of schizophrenia and other non-affective psychoses: cohort study of 1.3 million people in Sweden. BMJ 352:i1030. 10.1136/bmj.i1030.

Iwata H, Mori E, Sakajo A, Aoki K, Maehara K, and Tamakoshi K. 2018. Course of maternal fatigue and its associated factors during the first 6 months postpartum: a prospective cohort study. Nursing open 5:186-196. 10.1002/nop2.130

Khawaja NG, Hebbani A, Obijiofor L, and Gallois C. 2017. Refugee Parents' Communication and Relations With Their Children: Development and Application of the Refugee ParentChild Relational Communication Scale. Journal of Family Communication 17:372-385. $10.1080 / 15267431.2017 .1362409$

Kohler J. 2014. Health Sector Humanitarian Response Strategy: Jordan 2014-2015. . In: Group HSW, editor. Available at https://reliefweb.int/sites/reliefweb.int/files/resources/HealthSectorStrategyUpdateFinal1 4-06-2015.pdf ( accessed 8 March 2020) 
375 Lillee A, Thambiran A, and Laugharne J. 2015. Evaluating the mental health of recently arrived 376 refugee adults in Western Australia. Journal of Public Mental Health 14:56-68.

377

378

379

380

381

382

383

384

385

386

387

388

389

390

391

392

393

394

395

396

397

10.1108/JPMH-05-2013-0033

Matalqah LM, Radaideh KM, Khatatbeh MM, and Al Omari O. 2018. Factor associated with health-related quality of life among population in Northern Jordan. Epidemiology, Biostatistics Public Health 15. https://doi.org/10.2427/1

Maximova K, and Krahn H. 2010. Health status of refugees settled in Alberta: changes since arrival. Can J Public Health 101:322-326.

McHorney CA, Ware JE, Jr., Lu JF, and Sherbourne CD. 1994. The MOS 36-item Short-Form Health Survey (SF-36): III. Tests of data quality, scaling assumptions, and reliability across diverse patient groups. Med Care 32:40-66.

Mirghafourvand M, Charandabi SM-A, Jafarabadi MA, Tavananezhad N, and Karkhane M. 2016. Predictors of Health-Related Quality of Life in Iranian Women of Reproductive Age. Applied Research in Quality of Life 11:723-737. 10.1007/s11482-015-9392-0

Mortazavi F, Mousavi SA, Chaman R, and Khosravi A. 2014. Maternal quality of life during the transition to motherhood. Iranian Red Crescent medical journal 16:e8443-e8443. 10.5812/ircmj.8443

Nelson-Peterman JL, Toof R, Liang SL, and Grigg-Saito DC. 2015. Long-Term Refugee Health: Health Behaviors and Outcomes of Cambodian Refugee and Immigrant Women. Health Educ Behav 42:814-823. 10.1177/1090198115590779

Reese Masterson A, Usta J, Gupta J, and Ettinger AS. 2014. Assessment of reproductive health and violence against women among displaced Syrians in Lebanon. BMC Women's Health $14: 25.10 .1186 / 1472-6874-14-25$

Peer) reviewing PDF | (2020:05:48679:1:1:NEW 8 Aug 2020) 
398 Robinson SA, and Lachman ME. 2017. Perceived Control and Aging: A Mini-Review and 399 Directions for Future Research. Gerontology 63:435-442. 10.1159/000468540

400 Saadallah S, and Baker D. 2016. Women and Girls in the Syria Crisis: UNFPA Response. Egypt:

$401 \quad$ United Nations Population Fund. Available at

402 https://www.unfpa.org/sites/default/files/resource-pdf/UNFPA-FACTSANDFIGURES5\%5B4\%5D.pdf ( accessed 8 March 2020).

404 Sabbah I, Drouby N, Sabbah S, Retel-Rude N, and Mercier M. 2003. Quality of Life in rural and urban populations in Lebanon using SF-36 Health Survey. Health and Quality of Life Outcomes 1:30. 10.1186/1477-7525-1-30

407 408 409 410 411 412 413 414 415 416 417 418 419

Sadat Z, Taebi M, Saberi F, and Kalarhoudi MA. 2013. The relationship between mode of delivery and postpartum physical and mental health related quality of life. Iran J Nurs Midwifery Res 18:499-504.

Schmied V, Black E, Naidoo N, Dahlen HG, and Liamputtong P. 2017. Migrant women's experiences, meanings and ways of dealing with postnatal depression: A metaethnographic study. PloS one 12:e0172385-e0172385. 10.1371/journal.pone.0172385 Sevinç S, Kılıç SP, Ajghif M, Öztürk MH, and Karadağ E. 2016. Difficulties encountered by hospitalized Syrian refugees and their expectations from nurses. International nursing review 63:406-414. 10.1111/inr.12259

Sheikh KA, Yagoub U, Elsatouhy M, Al Sanosi R, and Mohamud SA. 2015. Reliability and validity of the arabic Version of the SF-36 health survey questionnaire in population of Khat Chewers - Jazan Region-Kingdom of Saudi Arabia. Applied Research in Quality of Life 10:1-13. https://doi.org/10.1007/s11482-013-9291-1 
420 Taylor EM, Yanni EA, Pezzi C, Guterbock M, Rothney E, Harton E, Montour J, Elias C, and

421

422

423

424

425

426

427

428

429

430

431

432

433

434

435

436

437

438

439

440

441

Burke H. 2014. Physical and mental health status of Iraqi refugees resettled in the United States. J Immigr Minor Health 16:1130-1137. 10.1007/s10903-013-9893-6

Tucker JN, Grzywacz JG, Leng I, Clinch CR, and Arcury TA. 2010. Return to Work, Economic Hardship, and Women's Postpartum Health. Women \& Health 50:618-638.

$10.1080 / 03630242.2010 .522468$

UNHCR. 2018a. Jordan: Fact Sheet. Available at https://reliefweb.int/sites/reliefweb.int/files/resources/FactSheetJordanFebruary2018FINAL_0.pdf(accessed 10 December 2018).

UNHCR. 2018b. UNHCR Fact sheet: Jordan. Available at https://reliefweb.int/sites/reliefweb.int/files/resources/66556.pdf(accessed 15 February 2020).

United Nations High Commissioner for Refugees (UNHCR). 2019. Syria emergency. Available at https://www.unhcr.org/syria-emergency.html (accessed 12 December 2019).

United Nations High Commissioner for Refugees (UNHCR). 2019. Syria Regional refugee response: Jordan. Available at https://data2.unhcr.org/en/situations/syria/location/36 (accessed 15 February 2020).

Ware JE, Jr., and Sherbourne CD. 1992. The MOS 36-item short-form health survey (SF-36). I. Conceptual framework and item selection. Med Care 30:473-483.

Weinstein N, Khabbaz F, and Legate N. 2016. Enhancing need satisfaction to reduce psychological distress in Syrian refugees. Journal of Consulting and Clinical Psychology 84:645-650. 10.1037/ccp0000095 
442 Wilson IB, and Cleary PD. 1995. Linking Clinical Variables With Health-Related Quality of 443 Life: A Conceptual Model of Patient Outcomes. JAMA 273:59-65.

$444 \quad$ 10.1001/jama.1995.03520250075037 \%J JAMA

445 World Bank. 2017. Jordan Country reclassification - Questions and Answers. Available at 446 https://www.worldbank.org/en/country/jordan/brief/qa-jordan-country-reclassification $447 \quad$ (accessed 12 December 2019).

448

449 
Table $\mathbf{1}$ (on next page)

Characteristics of women and their living conditions $(\mathrm{N}=523)$ 
1 Table 1 Characteristics of women and their living conditions $(\mathbf{N}=\mathbf{5 2 3})$

\begin{tabular}{lcc}
\hline Characteristics & Mean (SD) & $\mathbf{n}(\%)$ \\
\hline Age & $26.11(6.11)$ & \\
Years of marriage & $7.59(5.26)$ & \\
Age of women on marriage & $18.5(3.71)$ & \\
Family income & $222.6(105.54)$ & \\
Number of children & $3.2(1.84)$ & \\
Antenatal care & & \\
Yes & & $470(89.9)$ \\
$\quad$ No & $53(10.1)$ \\
Violence experience & \\
Yes & $34(6.5)$ \\
$\quad$ No & & \\
Abortion & & \\
$\quad$ Zero time & $328(62.7)$ \\
One time & $113(21.6)$ \\
Two times & $51(9.8)$ \\
Three times & $22(4.2)$ \\
$\quad$ Four and more & $9(1.8)$ \\
Baby loss & \\
Yes & & \\
No & & $50(9.6)$ \\
\hline
\end{tabular}

2 


\section{Table 2 (on next page)}

Means and standard deviations for the health scales $(N=523)$ 
1 Table 2: Means and standard deviations for the health scales $(\mathbf{N}=\mathbf{5 2 3})$

2

\begin{tabular}{lllc}
\hline Health scales & Means & $\begin{array}{c}\text { Standard } \\
\text { deviations }\end{array}$ & $\begin{array}{c}\text { Cronbach's } \\
\text { Alpha }\end{array}$ \\
\hline Physical functioning & 66.18 & 28.50 & .90 \\
Role physical & 46.80 & 43.88 & .90 \\
Role emotional & 42.83 & 44.31 & .88 \\
Energy - fatigue & 46.24 & 20.78 & .61 \\
Emotional wellbeing & 53.76 & 20.47 & .68 \\
Social functioning & 62.86 & 27.71 & .66 \\
Pain & 56.12 & 30.17 & .88 \\
General health & 57.56 & 19.92 & .61 \\
\hline
\end{tabular}

3 
Table 3 (on next page)

Table 3: Bivariate correlations between health scales and specific conditions for Syrian refugee's women 
1 Table 3: Bivariate correlations between health scales and specific conditions for Syrian

2 refugee's women

3

\begin{tabular}{|c|c|c|c|c|c|c|c|c|c|}
\hline $\begin{array}{l}\text { Health } \\
\text { scales }\end{array}$ & $\begin{array}{l}\text { Violence } \\
\text { experience }\end{array}$ & $\begin{array}{c}\text { Years } \\
\text { married }\end{array}$ & $\begin{array}{c}\text { Age } \\
\text { married }\end{array}$ & $\begin{array}{l}\text { Number } \\
\text { of } \\
\text { children }\end{array}$ & $\begin{array}{l}\text { Family } \\
\text { income }\end{array}$ & $\begin{array}{l}\text { Previous } \\
\text { birth }\end{array}$ & $\begin{array}{l}\text { Previous } \\
\text { abortion }\end{array}$ & $\begin{array}{l}\text { Baby } \\
\text { loss }\end{array}$ & $\begin{array}{l}\text { Antenatal } \\
\text { care }\end{array}$ \\
\hline $\begin{array}{l}\text { Physical } \\
\text { functioning }\end{array}$ & -.02 & $-.18^{* *}$ & $-.13^{* *}$ & $-.15^{* *}$ & $.12^{* *}$ & $-.15^{* *}$ & -.05 & .08 & $.09^{*}$ \\
\hline $\begin{array}{l}\text { Role } \\
\text { physical }\end{array}$ & .04 & $-.15^{* *}$ & -.06 & $-.13^{* *}$ & .05 & $-.12^{* *}$ & $-.12^{* *}$ & .06 & .04 \\
\hline $\begin{array}{l}\text { Role } \\
\text { emotional }\end{array}$ & .04 & $-.14^{* *}$ & -.08 & $-.11^{*}$ & .07 & $-.10^{*}$ & $-.10^{*}$ & .03 & $.11^{*}$ \\
\hline $\begin{array}{l}\text { Energy - } \\
\text { fatigue }\end{array}$ & .06 & $-.19^{* *}$ & -.06 & $-.21^{* *}$ & -.01 & $-.20^{* *}$ & -.04 & .04 & .073 \\
\hline $\begin{array}{l}\text { Emotional } \\
\text { wellbeing }\end{array}$ & $-.10^{*}$ & $-.13^{* *}$ & $-.09^{*}$ & $-.14^{* *}$ & .02 & $-.13^{* *}$ & $-.09^{*}$ & -.03 & .06 \\
\hline $\begin{array}{l}\text { Social } \\
\text { functioning }\end{array}$ & .01 & $-.16^{* *}$ & -.03 & $-.12^{* *}$ & .04 & $-.12^{* *}$ & -.06 & .01 & .08 \\
\hline Pain & .03 & $-.21^{* *}$ & -.06 & $-.18^{* *}$ & -.01 & $-.17^{* *}$ & $-.12^{* *}$ & .07 & $.12^{* *}$ \\
\hline $\begin{array}{l}\text { General } \\
\text { health }\end{array}$ & $-.10^{*}$ & $-.16^{* *}$ & -.08 & $-.15^{* *}$ & $.11^{*}$ & $-.16^{* *}$ & $-.13^{* *}$ & .03 & $.10^{*}$ \\
\hline
\end{tabular}




\section{Table 4 (on next page)}

Refugee women's characteristics as predictors for the health conditions 
Table 4: Refugee women's characteristics as predictors for the health conditions

\begin{tabular}{|c|c|c|c|c|c|c|c|c|}
\hline & $\begin{array}{l}\text { Physical } \\
\text { functioning }\end{array}$ & $\begin{array}{c}\text { Role } \\
\text { physical }\end{array}$ & $\begin{array}{c}\text { Role } \\
\text { emotional }\end{array}$ & $\begin{array}{l}\text { Energy - } \\
\text { fatigue }\end{array}$ & $\begin{array}{l}\text { Emotional } \\
\text { wellbeing }\end{array}$ & $\begin{array}{c}\text { Social } \\
\text { functioning }\end{array}$ & Pain & $\begin{array}{c}\text { General } \\
\text { health }\end{array}$ \\
\hline Predictors & $\begin{array}{c}\text { Beta } \\
\text { t-statistics }\end{array}$ & $\begin{array}{c}\text { Beta } \\
\text { t-statistics }\end{array}$ & $\begin{array}{c}\text { Beta } \\
\text { t-statistics }\end{array}$ & $\begin{array}{c}\text { Beta } \\
\text { t-statistics }\end{array}$ & $\begin{array}{c}\text { Beta } \\
\text { t-statistics }\end{array}$ & $\begin{array}{c}\text { Beta } \\
\text { t-statistics }\end{array}$ & $\begin{array}{c}\text { Beta } \\
\text { t-statistics }\end{array}$ & $\begin{array}{c}\text { Beta } \\
\text { t-statistics }\end{array}$ \\
\hline $\begin{array}{l}\text { Years } \\
\text { married }\end{array}$ & $\begin{array}{c}-.20 \\
-2.46^{* *}\end{array}$ & $\begin{array}{c}-.12 \\
-1.44\end{array}$ & $\begin{array}{c}-.17 \\
-1.94^{*}\end{array}$ & $\begin{array}{c}.04 \\
-0.49\end{array}$ & $\begin{array}{c}.03 \\
-0.38\end{array}$ & $\begin{array}{c}-.20 \\
-2.43\end{array}$ & $\begin{array}{c}-.18 \\
-2.18^{*}\end{array}$ & $\begin{array}{c}-.08 \\
-0.96\end{array}$ \\
\hline $\begin{array}{l}\text { Age } \\
\text { married }\end{array}$ & $\begin{array}{c}-.13 \\
-3.00^{* *}\end{array}$ & $\begin{array}{c}-.06 \\
-1.35\end{array}$ & $\begin{array}{l}-.08 \\
-1.71\end{array}$ & $\begin{array}{c}-.07 \\
-1.60\end{array}$ & $\begin{array}{c}-.09 \\
-1.96^{*}\end{array}$ & $\begin{array}{l}-.04 \\
-0.85\end{array}$ & $\begin{array}{c}-.07 \\
-1.62\end{array}$ & $\begin{array}{c}-.07 \\
-1.66\end{array}$ \\
\hline $\begin{array}{l}\text { Number } \\
\text { of } \\
\text { children }\end{array}$ & $\begin{array}{c}-.07 \\
-0.43\end{array}$ & $\begin{array}{c}-.28 \\
-1.56\end{array}$ & $\begin{array}{c}-.06 \\
-0.32\end{array}$ & $\begin{array}{c}-.26 \\
-1.50\end{array}$ & $\begin{array}{c}-.16 \\
-0.88\end{array}$ & $\begin{array}{c}.06 \\
0.35\end{array}$ & $\begin{array}{c}-.19 \\
-1.09\end{array}$ & $\begin{array}{l}.10 \\
0.58\end{array}$ \\
\hline $\begin{array}{l}\text { Family } \\
\text { income }\end{array}$ & $\begin{array}{c}.11 \\
2.53^{* *}\end{array}$ & $\begin{array}{c}.04 \\
0.97\end{array}$ & $\begin{array}{c}.06 \\
1.24\end{array}$ & $\begin{array}{c}-.02 \\
-0.35\end{array}$ & $\begin{array}{c}.01 \\
0.16\end{array}$ & $\begin{array}{c}.04 \\
0.88\end{array}$ & $\begin{array}{c}-.02 \\
-0.38\end{array}$ & $\begin{array}{c}.11 \\
2.48^{* *}\end{array}$ \\
\hline $\begin{array}{l}\text { Previous } \\
\text { birth }\end{array}$ & $\begin{array}{c}.09 \\
0.54\end{array}$ & $\begin{array}{l}.27 \\
1.57\end{array}$ & $\begin{array}{l}.10 \\
0.60\end{array}$ & $\begin{array}{c}.10 \\
0.59\end{array}$ & $\begin{array}{c}.06 \\
0.32\end{array}$ & $\begin{array}{l}-.01 \\
-0.05\end{array}$ & $\begin{array}{l}.19 \\
1.15\end{array}$ & $\begin{array}{c}-.18 \\
-1.04\end{array}$ \\
\hline $\begin{array}{l}\text { Previous } \\
\text { abortion }\end{array}$ & $\begin{array}{c}.01 \\
0.04\end{array}$ & $\begin{array}{c}-.09 \\
-1.99^{*}\end{array}$ & $\begin{array}{c}-.07 \\
-1.50\end{array}$ & $\begin{array}{l}-.01 \\
-0.15\end{array}$ & $\begin{array}{l}-.07 \\
-1.52\end{array}$ & $\begin{array}{l}-.02 \\
-0.37\end{array}$ & $\begin{array}{c}-.08 \\
-1.83\end{array}$ & $\begin{array}{l}-.08 \\
-1.88\end{array}$ \\
\hline Baby loss & $\begin{array}{l}.05 \\
1.21\end{array}$ & $\begin{array}{l}.05 \\
1.09\end{array}$ & $\begin{array}{c}.01 \\
0.14\end{array}$ & $\begin{array}{c}.02 \\
0.49\end{array}$ & $\begin{array}{c}-.05 \\
-1.08\end{array}$ & $\begin{array}{l}-.03 \\
-0.60\end{array}$ & $\begin{array}{c}.04 \\
0.96\end{array}$ & $\begin{array}{l}-.01 \\
-0.07\end{array}$ \\
\hline $\begin{array}{l}\text { Antenatal } \\
\text { care }\end{array}$ & $\begin{array}{l}.05 \\
1.21\end{array}$ & $\begin{array}{c}.01 \\
0.26\end{array}$ & $\begin{array}{c}.08 \\
1.79\end{array}$ & $\begin{array}{c}.04 \\
0.86\end{array}$ & $\begin{array}{c}.03 \\
0.71\end{array}$ & $\begin{array}{l}.06 \\
1.24\end{array}$ & $\begin{array}{c}.09 \\
2.08^{*}\end{array}$ & $\begin{array}{c}.06 \\
1.28\end{array}$ \\
\hline $\begin{array}{l}\text { Violence } \\
\text { experience }\end{array}$ & $\begin{array}{c}-.04 \\
-0.91\end{array}$ & $\begin{array}{c}.03 \\
0.69\end{array}$ & $\begin{array}{c}.02 \\
0.55\end{array}$ & $\begin{array}{c}.04 \\
0.92\end{array}$ & $\begin{array}{c}.08 \\
1.84\end{array}$ & $\begin{array}{c}-.01 \\
-0.03\end{array}$ & $\begin{array}{c}.01 \\
0.15\end{array}$ & $\begin{array}{c}-.09 \\
-2.12^{*}\end{array}$ \\
\hline $\begin{array}{l}\mathbf{R} \\
\mathbf{R}^{2} \\
\end{array}$ & $\begin{array}{l}.27 \\
.07 \\
\end{array}$ & $\begin{array}{l}.21 \\
.05\end{array}$ & $\begin{array}{l}.21 \\
.04\end{array}$ & $\begin{array}{l}.23 \\
.05\end{array}$ & $\begin{array}{l}.21 \\
.04\end{array}$ & $\begin{array}{l}.18 \\
.03 \\
\end{array}$ & $\begin{array}{l}.27 \\
.07\end{array}$ & $\begin{array}{l}.27 \\
.07 \\
\end{array}$ \\
\hline
\end{tabular}




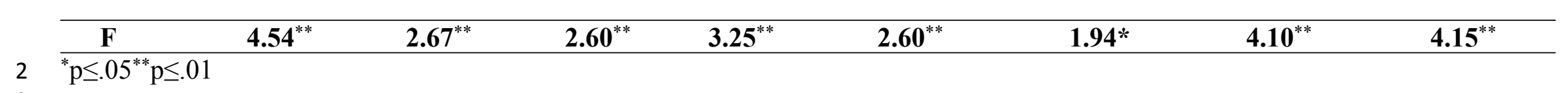

